Terr. Atmos. Ocean. Sci., Vol. 18, No. 3, 475-492, August 2007

\title{
Changes in Nitrogen Dioxide and Ozone over Southeast and East Asia Between Year 2000 and 2030 with Fixed Meteorology
}

\author{
Michael Gauss ${ }^{1,}{ }^{*}$, Kjerstin Ellingsen ${ }^{1}$, Ivar S. A. Isaksen ${ }^{1}$, Frank J. Dentener ${ }^{2}$, \\ David S. Stevenson ${ }^{3}$, Markus Amann ${ }^{4}$, and Janusz Cofala ${ }^{4}$
}

(Manuscript received 18 August 2006, in final form 15 January 2007)

\begin{abstract}
In the framework of the European Network of Excellence ACCENT changes in near-surface and total tropospheric nitrogen dioxide $\left(\mathrm{NO}_{2}\right)$ and ozone from year 2000 to $\mathbf{2 0 3 0}$ have been calculated for the Southeast and East Asian regions using the chemical transport model Oslo CTM-2. Anthropogenic emissions of ozone precursors for the year 2000 case are taken from the International Institute for Applied Systems Analysis (IIASA). Regarding year 2030 emissions, three different scenarios are compared: 1) IIASA 'current legislation' (CLE), where current air quality legislation around the world is implemented; 2) IIASA 'maximum feasible reduction' (MFR), in which all currently available technologies are applied to achieve maximum emission reductions; and 3) the IPCC-SRES A2 scenario, which was used as a high emission estimate in the last IPCC assessment report. While increases in $\mathrm{NO}_{2}$ and ozone are calculated when using the CLE scenario, reductions are seen for the MFR scenario. In the SRES A2 case, increases in $\mathrm{NO}_{2}$ are largest, locally leading to ozone reductions at the surface resulting from titration effects. The model calculations suggest that air
\end{abstract}

${ }^{1}$ Department of Geosciences, University of Oslo, Oslo, Norway

2 European Commission, Joint Research Centre, Institute for Environment and Sustainability, Climate Change Unit, Ispra, Italy

${ }^{3}$ School of Geosciences, University of Edinburgh, Edinburgh, UK

4 International Institute for Applied Systems Analysis, Laxenburg, Austria

* Corresponding author address: Dr. Michael Gauss, Department of Geosciences, University of Oslo, Oslo, Norway; E-mail: michael.gauss@geo.uio.no doi: 10.3319/TAO.2007.18.3.475(EA) 


\title{
quality problems will be severely aggravated over Southeast and East Asia if current legislation is not attained.
}

\author{
(Key words: $\mathrm{NO}_{2}$ columns, Surface ozone, 3-D chemical transport modeling, \\ Future air quality, Southeast Asia, East Asia, Emission scenarios)
}

\section{INTRODUCTION}

The Southeast and East Asian regions, and China in particular, have been characterized by rapid economic growth during the last two decades. This growth is projected to continue at a faster pace than in other industrialized parts of the world in the coming years (e.g., IMF 2006). Anthropogenic emissions of ozone precursors, notably nitrogen oxides $\left(\mathrm{NO}_{\mathrm{x}} \equiv \mathrm{NO}+\mathrm{NO}_{2}\right)$, carbon monoxide, and volatile organic compounds, are assumed to increase accordingly. Nitrogen dioxide $\left(\mathrm{NO}_{2}\right)$, which is the focus of the present paper, catalyzes tropospheric ozone production and thus plays a key role in the oxidizing capacity of the atmosphere. $\mathrm{NO}_{2}$ is toxic to the biosphere and can, when present in elevated levels, compromise human health. Converted into nitric acid $\left(\mathrm{HNO}_{3}\right)$ it contributes to acid rain, which is harmful to the entire ecosystem. Furthermore, $\mathrm{NO}_{2}$ has indirect significance for climate change due to its strong chemical interactions with greenhouse gases ozone and methane.

The main sources of $\mathrm{NO}_{2}$ are anthropogenic emissions from industry, domestic energy consumption, the transport sector, and biomass burning. Important natural sources include lightning, and microbial activity in soils. The main sink of $\mathrm{NO}_{2}$ is its oxidation to $\mathrm{HNO}_{3}$ that is lost by wet removal, and to $\mathrm{N}_{2} \mathrm{O}_{5}$ that is hydrolyzed on aerosols. Due to its comparatively short lifetime and the heterogeneity of its sources, $\mathrm{NO}_{2}$ shows great variability in both space and in time.

Ozone, being produced in the troposphere from the oxidation of $\mathrm{CO}$ and hydrocarbons in the presence of $\mathrm{NO}_{\mathrm{x}}$ and sunlight, has a direct impact on climate (Gauss et al. 2006a) and air quality (Prather et al. 2003). As in the case of $\mathrm{NO}_{2}$, its distribution is highly variable in space and time in contrast to well-mixed greenhouse gases. Assessments of future changes in climate and air quality due to $\mathrm{NO}_{\mathrm{x}}$ and ozone thus require detailed 3-dimensional model calculations.

Within ACCENT, a network of excellence funded by the European Commission, a multimodel study (hereafter referred to as 'ACCENT experiment') involving 26 state-of-the-art atmospheric chemistry models from Europe, Japan and the US has been performed with focus on air quality and climate change. The time horizon for the ACCENT experiment was chosen to be 2030, considered to be of high importance for policy makers and near-future mitigation strategies regarding air quality. Publications that have evolved from the ACCENT experiment include calculations of present-day and near future global tropospheric ozone distributions, budgets and associated radiative forcings (Stevenson et al. 2006), changes in surface ozone and impacts on human health and vegetation (Ellingsen et al. 2006), a detailed analysis of nitrogen and sulfur deposition budgets (Dentener et al. 2006a), an inter-comparison and evaluation of present-day $\mathrm{NO}_{2}$ columns (van Noije et al. 2006), and tropospheric carbon monoxide (Shindell et al. 2006). 
The present paper presents results obtained as part of the ACCENT experiment with the chemical transport model, Oslo CTM-2, and investigates future change in near-surface $\mathrm{NO}_{2}$ and ozone as well as tropospheric column abundances specifically for the Southeast and East Asian regions. A relatively high horizontal resolution combined with the global coverage of the model enables us to take into account not only effects from alterations in local emissions but also the influence from changes in other regions of the world through long-range transport of both primary and secondary pollutants.

A description of the model tool is given in the next section, followed by an outline of the experimental setup in section 3. Results are presented in section 4, while section 5 concludes the paper with a brief summary of our main findings.

\section{MODEL DESCRIPTION}

The Oslo CTM-2 (referred to in the following as 'CTM2') is a global 3-dimensional chemical transport model driven by ECMWF meteorological data extending from the ground to $10 \mathrm{hPa}$ in 40 vertical layers with a vertical resolution in the order of tens of meters in the planetary boundary layer. The horizontal resolution can be varied, but is set to Gaussian T42 $\left(\sim 2.8^{\circ} \times 2.8^{\circ}\right)$ for this study. Advection uses the highly accurate Second Order Moment scheme of Prather (1986), while convection is based on the Tiedtke (1989) mass flux scheme. Transport in the boundary layer is treated according to the Holtslag K-profile method (Holtslag et al. 1990), and the calculation of dry deposition follows Wesely (1989).

Surface emissions are based on the EDGAR 3.2 data base (Olivier and Berdowski 2001), but have been modified for this study as described in detail in section 3. Lightning emissions of $\mathrm{NO}_{\mathrm{x}}$ are parameterized based on formulas by Price et al. (1997a, b), distributing the emissions according to convective activity in the model and choosing $5 \mathrm{Tg}(\mathrm{N}) \mathrm{yr}^{-1}$ as total annual output. The model calculates the distribution of 58 chemical compounds through a comprehensive tropospheric chemistry module (Berntsen and Isaksen 1997, 1999) using the QSSA numerical solver (Hesstvedt et al. 1978) and including a recently developed sulfur module (Berglen et al. 2004). Stratospheric boundary conditions are pre-calculated by another version of the model that includes a comprehensive stratospheric chemistry module (Gauss et al. 2006b). Photo-dissociation rates are calculated online by the Fast-J module (Wild et al. 2000), taking into account changing ozone distributions and the scattering of sunlight by clouds.

The model has been tested and evaluated recently by Berglen et al. (2004), Brunner et al. (2005), and Isaksen et al. (2005). Results from the CTM2 calculations used in this paper have been evaluated against ozone sondes in (Stevenson et al. 2006, see the "Auxiliary Material" of that paper) and in (Ellingsen et al. 2006). Also, $\mathrm{NO}_{2}$ (van Noije et al. 2006, see in particular their Fig. 10 for Eastern China), and carbon monoxide (Shindell et al. 2006) have been evaluated in the ACCENT experiment. In most cases, the results of CTM2 are well within the range of results from the other models that have participated in the experiment and also well within the standard deviation of the measurements. Deviations from the model mean include the lifetime of methane, which amounts to 8 years and, although not unreasonable, is near the lower end of the model range (Shindell et al. 2006), and the ratio of $\mathrm{HNO}_{3}$ to total $\mathrm{NO}_{\mathrm{x}}$ deposition as well as wet deposition to total deposition of sulphur oxides, which is at the upper end 
of the model range (Dentener et al. 2006a). An evaluation of the model with a stronger focus on Southeast and East Asia is presented for ozone, $\mathrm{CO}$, and $\mathrm{NO}_{\mathrm{x}}$ in this special issue by Liu et al. (2007). Recent comparisons of CTM2 near surface ozone have revealed overestimations over India (Ellingsen et al. 2006). However, this is in part due to the coastal location of the measurement sites used in that study, which are influenced by unpolluted marine air. Differences between present and future levels, which are in focus in the present study are, given the relatively small model deviations, assumed to be influenced only to a minor degree by the ozone background.

\section{EXPERIMENTAL SETUP}

Details of the design of the ACCENT experiment, in which the results presented in this paper were generated, have been published elsewhere (e.g., Dentener et al. 2006b; Stevenson et al. 2006). Here, we briefly review the features that are relevant for the present study focusing on Southeast and East Asia.

The four simulations presented in this paper are listed in Table 1. We calculate one present case for the reference year 2000 (hereafter labeled as '2000') and three future cases based on different emission scenarios. To reduce the required spin-up time in the model calculations, tropospheric mixing ratios of the long-lived species methane $\left(\mathrm{CH}_{4}\right)$ are prescribed as specified in Table 1.

Anthropogenic emissions of the shorter-lived ozone precursors in the present case are based on national estimates from the International Institute for Applied Systems Analysis (IIASA) for the year 2000 (Cofala et al. 2006; Dentener et al. 2005), distributed according to the Emission Database for Global Atmospheric Research (EDGAR) version 3.2 for the year 1995 (Olivier and Berdowski 2001). Emissions from international shipping are extrapolated from the EDGAR3.2 emissions for 1995 assuming a growth rate of $1.5 \%$ per year. For aircraft $\mathrm{NO}_{\mathrm{x}}$ emissions a total of $0.79 \mathrm{Tg}(\mathrm{N}) \mathrm{yr}^{-1}$ is used with distributions from NASA (Baughcum et al. 1996).

Table 1. Model runs performed in the experiment. Details on the emission scenarios are given in the text.

\begin{tabular}{|c|c|c|c|}
\hline Run & Emissions & Description & $\mathbf{C H}_{4}$ \\
\hline 2000 & IIASA-2000 & baseline & $1760 \mathrm{ppb}$ \\
\hline CLE & IIASA-CLE-2030 & IIASA Business As Usual (current legislation) & $2088 \mathrm{ppb}$ \\
\hline MFR & IIASA-MFR-2030 & $\begin{array}{l}\text { IIASA MFR (Maximum Feasible Reduction } \\
\text { optimistic technology scenario) }\end{array}$ & $1760 \mathrm{ppb}$ \\
\hline $\mathbf{A 2}$ & SRES-A2-2030 & $\begin{array}{l}\text { SRES A2 (the most 'pessimistic' IPCC } \\
\text { SRES scenario) }\end{array}$ & $2163 \mathrm{ppb}$ \\
\hline
\end{tabular}


The IIASA emission datasets used for the year 2030 simulations are described in detail by Cofala et al. (2006). The first scenario (hereafter referred to as 'CLE' for Current LEgislation) assumes country-, sector- and technology-specific emission control measures that are imposed by present (2002) legislation. Country-specific information for Southeast and East Asia was collected during the RAINS-Asia II project (IIASA 2001; Boudri et al. 2002) and updated with recent information on mobile sources from the Clean Air Initiative of the World Bank.

The second future scenario ('MFR' for Maximum Feasible Reduction) assumes the implementation of all currently available technologies towards emission control in order to reduce anthropogenic emissions as much as possible. It does, however, not account for emission reductions through structural changes, such as increased energy efficiency measures, fuel substitution or reduced transport demand.

Unlike the CLE and MFR scenarios, the pessimistic IPCC Special Report on Emission Scenarios (SRES) A2 scenario (Nakicenovic et al. 2000) does not consider air pollution control legislation, even if this legislation was already in place in the year 2000. This scenario (hereafter referred to as 'A2') serves to illustrate what happens if emission control legislation is not attained. It has been used in this study to get an upper estimate of atmospheric change, and to allow for a comparison with earlier studies. Aircraft emissions for the three future simulations are implemented with the same spatial distribution as in the present simulation, but scaled up to a total global emission of $1.73 \mathrm{Tg}(\mathrm{N}) \mathrm{yr}^{-1}$.

Surface emissions of $\mathrm{NO}_{\mathrm{x}}$, carbon monoxide, non-methane volatile organic compounds, sulfur dioxide, and ammonia from anthropogenic sources are specified as annual means $1^{\circ} \times 1^{\circ}$ grid for the present case and the three future cases, including separate source categories for industry, the domestic sector, and surface traffic. The resulting emissions of $\mathrm{NO}_{\mathrm{x}}$ are integrated in Table 2 for the whole world and for the Southeast and East Asian regions, defined in this paper as the area between 0 and 55 degrees north and between 65 and 145 degrees east. The table clearly reflects the benefits in the MRF scenario in terms of emission reductions, especially in the industrial and transport sectors, while A2, which was used in IPCC-TAR (Prather et al. 2001) as a 'worst case' scenario, is characterized by substantial increases in all sectors, both on a global scale and over Southeast and East Asia.

Total natural emissions used in CTM2 are listed in Table 3. The speciation of non-methane hydrocarbons (NMHC) is based on Table 4.7 in the IPCC-TAR report (Prather et al. 2001). First, components included in the IPCC-TAR table but not in CTM2 are removed from the NMHC emission total of the IPCC-TAR table. Then, the percent fractions of each of the remaining species are calculated for the IPCC-TAR table. Using these percent fractions, the emissions of each species is then calculated based on the new NMHC emission total suggested by IIASA.

Since uncertainties in the change of natural emissions due to climate change and changes in vegetation remain large we chose in the ACCENT experiment to keep these emissions unchanged in the future scenarios. Also, as we focus on the troposphere we have kept stratospheric boundary conditions fixed, i.e., the stratospheric boundary condition that was precalculated by the stratospheric version of CTM2, is used for all scenarios addressed in this study. Biomass burning emissions are based on EDGAR3.2 (Olivier and Berdowski 2001), 
which uses the Global Fire Emissions Database (van der Werf et al. 2003). Biomass burning adds a total of $33.4 \mathrm{Tg}(\mathrm{N}) \mathrm{yr}^{-1}$ globally in all scenarios and is distributed over several emission heights between the surface and $6 \mathrm{~km}$, to account for fast vertical transport within smoke plumes. Sources of biomass burning in this study include tropical forest fires, deforestation, savannah and shrubs fires, temperate vegetations fires, agricultural waste burning, and middle to high latitude forest and grass land fires.

The model meteorology is based on year 2000 ECMWF data in all simulations, i.e., effects from climate change between 2000 and 2030 are not considered in the CTM2 simulations to be presented here, but were taken into account in the coupled chemistry-climate models participating in the ACCENT experiment and further discussed by Stevenson et al. (2006).

Table 2. Anthropogenic $\mathrm{NO}_{\mathrm{x}}$ (as $\mathrm{NO}_{2}$ ) emission totals in the world and for Southeast and East Asia (defined here as the region $0^{\circ} \mathrm{N}-55^{\circ} \mathrm{N}$ and $65^{\circ} \mathrm{E}$ $\left.145^{\circ} \mathrm{E}\right)$ for the year 2000 and the three future (2030) scenarios. IND: fossil fuel burning and industrial emissions, DOM: domestic sources, and TRA: transport sector. Unit: $\operatorname{Tg}(\mathrm{N}) \mathrm{yr}^{-1}$. The numbers in parentheses represent the changes with respect to year 2000.

\begin{tabular}{|c|c|c|c|c|c|}
\hline & & IND & DOM & TRA & TOTAL \\
\hline \multirow{2}{*}{2000} & world & 33.7 & 4.88 & 52.8 & 91.4 \\
\hline & SE/E Asia & 12.3 & 1.74 & 13.2 & 27.2 \\
\hline \multirow{2}{*}{ CLE } & world & $\begin{array}{l}36.3 \\
(+7.6 \%)\end{array}$ & $\begin{array}{l}6.10 \\
(+25.3 \%)\end{array}$ & $\begin{array}{l}65.3 \\
(+23.7 \%)\end{array}$ & $\begin{array}{l}107.7 \\
(+17.9 \%)\end{array}$ \\
\hline & SE/E Asia & $\begin{array}{l}17.1 \\
(+39.6 \%)\end{array}$ & $\begin{array}{l}2.10 \\
(+20.7 \%)\end{array}$ & $\begin{array}{l}19.9 \\
(+50.7 \%)\end{array}$ & $\begin{array}{l}39.1 \\
(+43.8 \%)\end{array}$ \\
\hline \multirow{2}{*}{ MRF } & world & $\begin{array}{l}10.8 \\
(-68.0 \%)\end{array}$ & $\begin{array}{l}4.31 \\
(-11.5 \%)\end{array}$ & $\begin{array}{l}28.1 \\
(-46.8 \%)\end{array}$ & $\begin{array}{l}43.2 \\
(-52.7 \%)\end{array}$ \\
\hline & $\mathrm{SE} / \mathrm{E}$ Asia & $\begin{array}{l}4.4 \\
(-64.1 \%)\end{array}$ & $\begin{array}{l}1.70 \\
(-0.58 \%)\end{array}$ & $\begin{array}{l}6.17 \\
(-53.3 \%)\end{array}$ & $\begin{array}{l}12.3 \\
(-54.8 \%)\end{array}$ \\
\hline \multirow{2}{*}{$\mathrm{A} 2$} & world & $\begin{array}{l}56.9 \\
(+68.8 \%)\end{array}$ & $\begin{array}{l}15.0 \\
(+207.2 \%)\end{array}$ & $\begin{array}{l}107.4 \\
(+103.6 \%)\end{array}$ & $\begin{array}{l}179.3 \\
(+96.3 \%)\end{array}$ \\
\hline & $\mathrm{SE} / \mathrm{E}$ Asia & $\begin{array}{l}22.7 \\
(+85.4 \%)\end{array}$ & $\begin{array}{l}4.87 \\
(+179.9 \%)\end{array}$ & $\begin{array}{l}35.6 \\
(+170.0 \%)\end{array}$ & $\begin{array}{l}63.2 \\
(+132.5 \%)\end{array}$ \\
\hline
\end{tabular}


Table 3. Natural emissions used in this study. Natural emissions are kept the same in the 2000 and 2030 simulations $(\mathrm{NMHC}=$ Non-methane hydrocarbons, DMS = dimethyl sulfide).

\begin{tabular}{l|ll}
\hline Component & Source/sink & Annual Amount \\
\hline $\mathrm{CO}$ & ocean/vegetation & $200 \mathrm{Tg} \mathrm{CO}$ \\
\hline $\mathrm{NO}_{\mathbf{x}}$ & lightning & $5 \mathrm{Tg} \mathrm{N}$ \\
& soils & ca. $5 \mathrm{Tg} \mathrm{N}$ \\
\hline $\mathrm{NMHC}$ & isoprene & $220 \mathrm{Tg} \mathrm{C}$ \\
& terpenes & $260 \mathrm{Tg} \mathrm{C}$ \\
\hline $\mathrm{SO}_{2}$ & volcanoes & $14.6 \mathrm{Tg} \mathrm{S}$ \\
\hline $\mathrm{DMS}$ & oceans/terrestrial & ca. $20 \mathrm{Tg} \mathrm{S}$ \\
\hline $\mathrm{NH}_{3}$ & oceans & $8.3 \mathrm{Tg} \mathrm{N}(10.1 \mathrm{Tg} \mathrm{NH} 3)$ \\
& soils & $2.4 \mathrm{Tg} \mathrm{N}(2.91 \mathrm{Tg} \mathrm{NH} 3)$ \\
\hline $\mathrm{O}_{3} / \mathrm{HNO}_{3}$-strat & year 2000 stratospheric conditions in all \\
& simulations & \\
& \multicolumn{2}{l}{} \\
\hline
\end{tabular}

\section{RESULTS}

The next section presents CTM2 model output for $\mathrm{NO}_{2}$ changes, while in section 4.2 the resulting changes in ozone are discussed.

\subsection{Changes in $\mathrm{NO}_{2}$}

Figure 1 shows spatial distributions of the surface mixing ratio and tropospheric column abundance of $\mathrm{NO}_{2}$ in the Southeast and East Asian regions as modeled by CTM2 for January and July 2000. The 150-ppb ozone surface was used as tropopause level for this analysis in accordance with IPCC (Prather et al. 2001), i.e., tropospheric column abundances represent the number of molecules between the surface and the 150-ppb ozone level. Maximum levels are modeled in the winter season, primarily due to less oxidation through $\mathrm{OH}$, which is present in lower concentrations during winter. $\mathrm{NO}_{2}$ columns are determined to a large degree by surface concentrations and thus resemble the distribution of near-surface $\mathrm{NO}_{2}$. However, the local maxima seen in $\mathrm{NO}_{2}$ column abundance over Eastern China exceed all other peaks of the region, amounting to about $14 \times 10^{15}$ molecules $\mathrm{cm}^{-2}$ in January and $9 \times 10^{15}$ molecules $\mathrm{cm}^{-2}$ in July. This is due to the spatially more extended emission sources and the resulting higher $\mathrm{NO}_{x}$ levels also in the free troposphere. A detailed evaluation of modeled $\mathrm{NO}_{2}$ columns has been published recently by van Noije et al. (2006), showing good agreement with observations, both in qualitative and quantitative terms. 


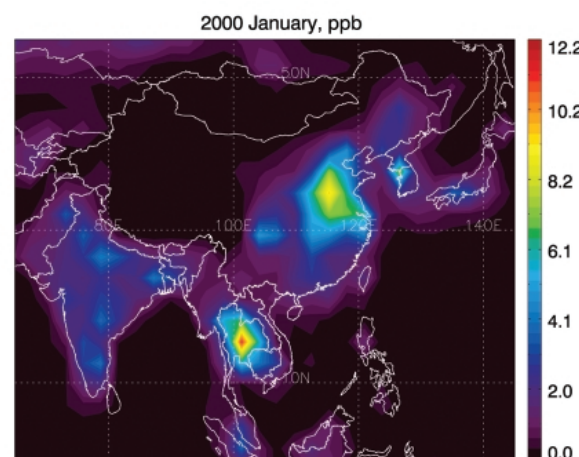

2000 January, $1 . e 15 \mathrm{molec} / \mathrm{cm} 2$

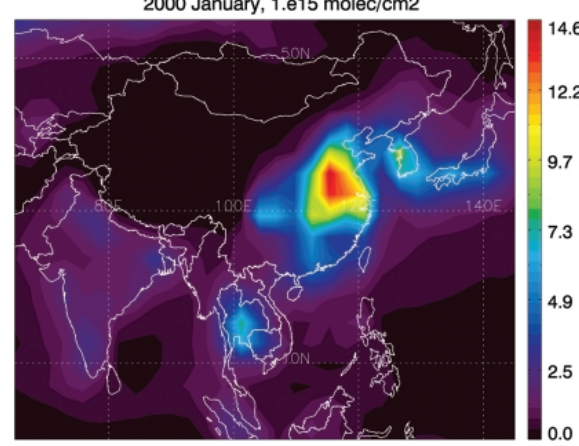

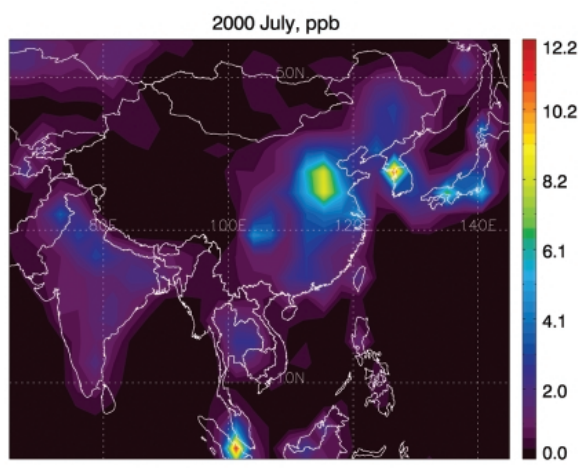

2000 July, 1.e15 molec/cm2

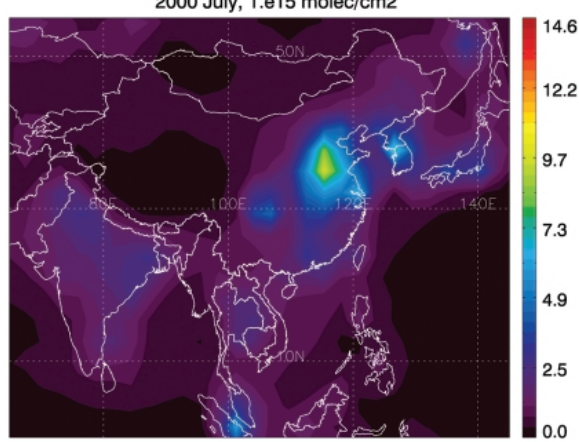

Fig. 1. Monthly-mean surface mixing ratio (top panels, ppb) and tropospheric columns (bottom panels, $10^{15}$ molecules $\mathrm{cm}^{-2}$ ) of $\mathrm{NO}_{2}$ in Southeast and East Asia in January and July 2000 as modeled by CTM2.

Figures 2 and 3 show changes in $\mathrm{NO}_{2}$ near-surface mixing ratio and tropospheric columns, respectively, for the three different future calculations. In general, increases are modeled for the CLE and A2 cases, while reductions are modeled for the MFR simulation. Changes in $\mathrm{NO}_{2}$ are controlled primarily by changes in $\mathrm{NO}_{x}$ emissions, but are also modified by changes in other species that interact with $\mathrm{NO}_{\mathrm{x}}$ and, in the case of total columns, by long-range transport of $\mathrm{NO}_{\mathrm{x}}$ in the free troposphere.

Regarding near-surface $\mathrm{NO}_{2}$ in the CLE scenario (top panels in Fig. 2), notable increases are seen in metropolitan areas, such as Lahore, Delhi, Dhaka, Beijing, Shanghai, and Seoul. Essentially, these are also the regions where there is potential for significant reductions, as revealed by the plots for the MFR scenario (middle panels in Fig. 2). Additional areas with large reductions seen in the MFR scenario are Thailand, Malaysia, and Japan. Not surprisingly, the largest increase is modeled in the A2 scenario (bottom panels in Fig. 2), with peaks exceeding 13 ppb in Eastern China and large increases in the densely populated areas of Northern India. 
By and large, changes in total tropospheric $\mathrm{NO}_{2}$ displayed in Fig. 3 allow the same conclusions. Major differences from the patterns seen in Fig. 2 include a much more pronounced increase in Eastern China and South Korea in the CLE scenario and a more pronounced reduction in Thailand, South Korea, and Japan in the MFR scenario. Apparently, changes in pollutants and in atmospheric composition in these regions are transported more efficiently into higher altitudes. It is worth noting that in Eastern China, total columns of $\mathrm{NO}_{2}$ can be reduced by more than $50 \%$ according to the MFR case. Largest increases are modeled in the A2 scenario, amounting to more than $25 \times 10^{15}$ molecules $\mathrm{cm}^{-2}$ in Eastern China during winter, which corresponds to more than a doubling with respect to the year 2000 simulation.
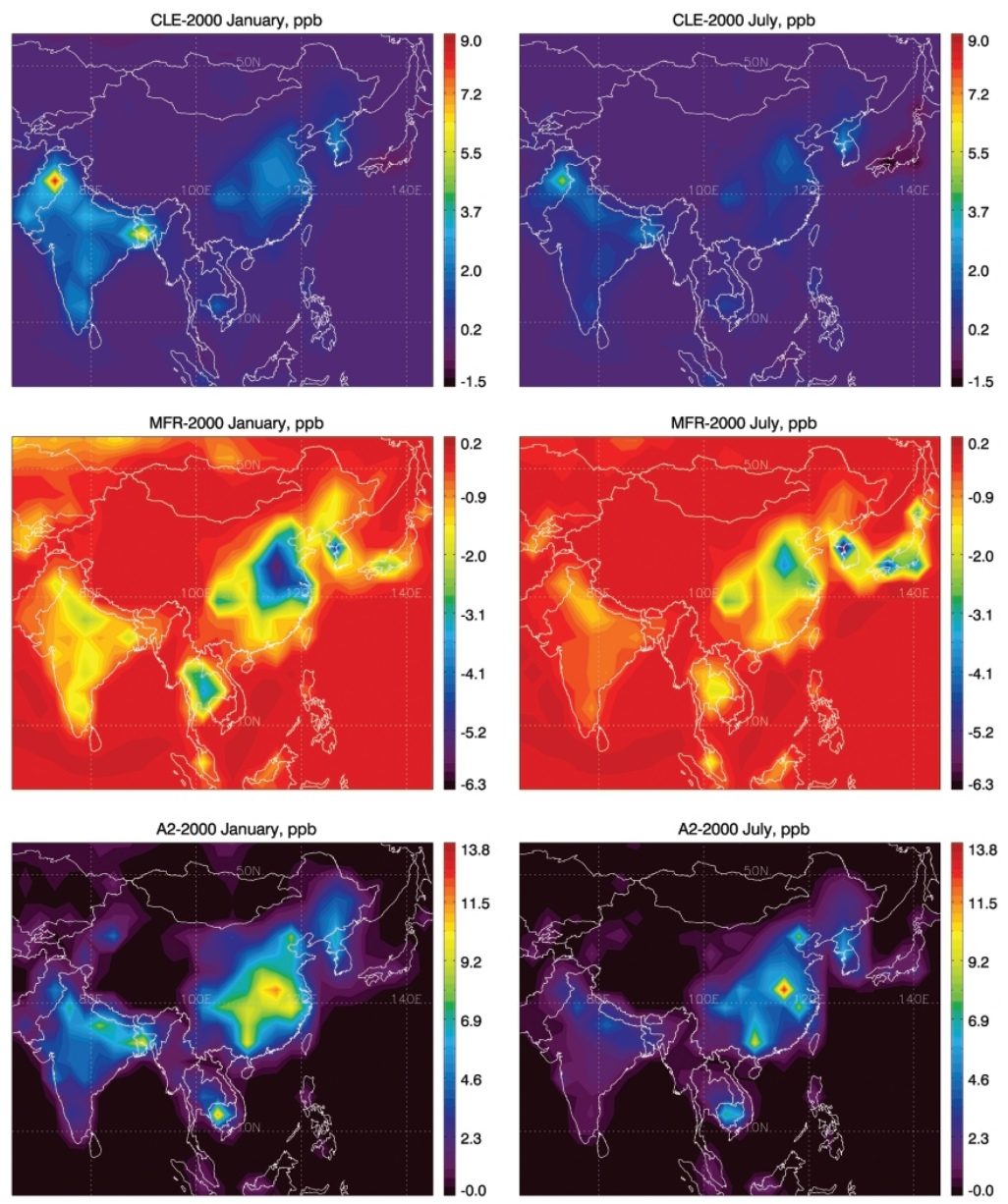

Fig. 2. Changes in monthly-mean surface $\mathrm{NO}_{2}$. Top panels: 'CLE minus 2000', middle panels: 'MFR minus 2000', bottom panels: 'A2 minus 2000'. Unit: ppb. Note the different color scale for the different scenarios. 


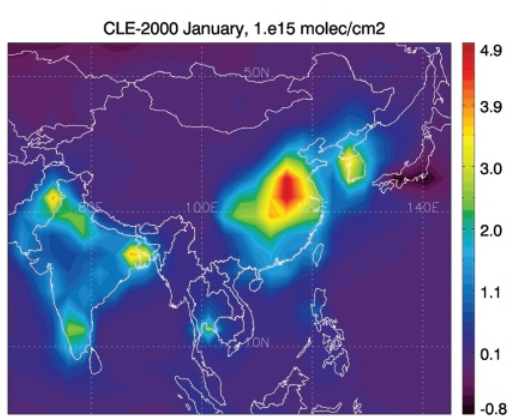

MFR-2000 January, $1 . e 15 \mathrm{molec} / \mathrm{cm} 2$

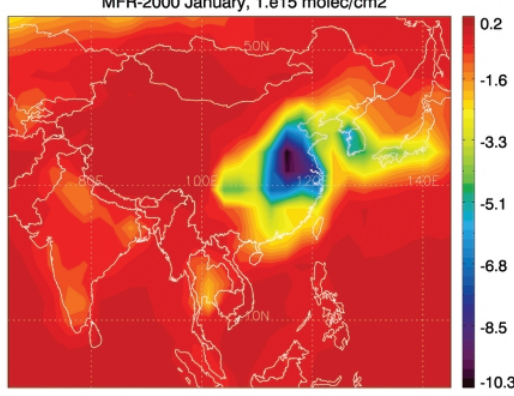

A2-2000 January, $1 . e 15 \mathrm{molec} / \mathrm{cm} 2$

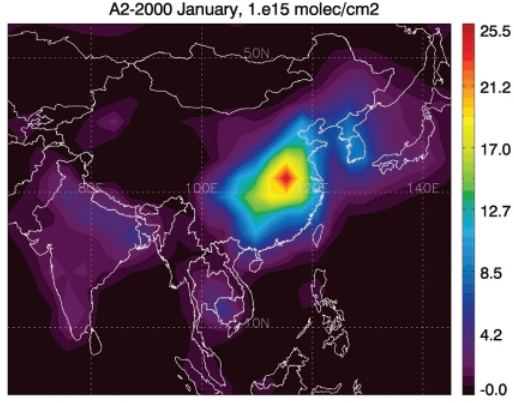

CLE-2000 July, $1 . e 15$ molec/cm2

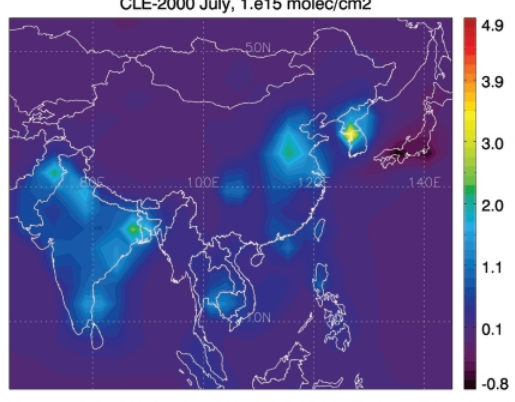

MFR-2000 July, $1 . e 15$ molec/cm2

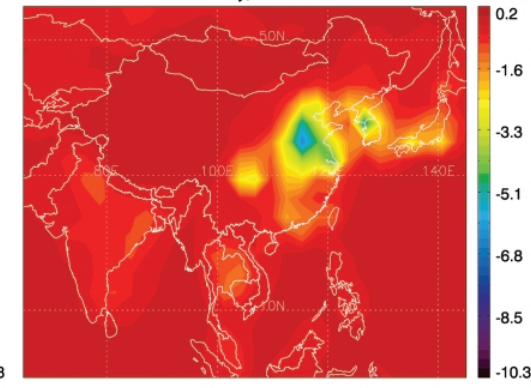

A2-2000 July, $1 . e 15 \mathrm{molec} / \mathrm{cm} 2$

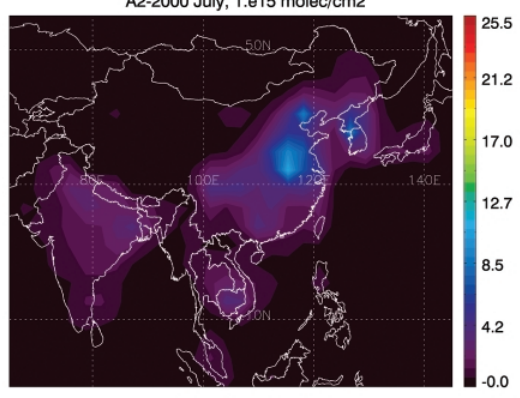

Fig. 3. Changes in the monthly-mean tropospheric $\mathrm{NO}_{2}$ column. Top panels: 'CLE minus 2000', middle panels: 'MFR minus 2000', bottom panels: 'A2 minus 2000'. Unit: $10^{15}$ molecules $\mathrm{cm}^{-2}$. Note the different color scale for the different scenarios.

\subsection{Changes in Ozone}

Distributions of near-surface ozone and the tropospheric ozone column are shown in Fig. 4. As ozone production is highly dependent on insolation the belt of maximum near-surface concentrations moves northward during Northern Hemisphere summer. In January local maxima are typically modeled off the coast lines of India and South-Eastern China. Ozone columns are a maximum over India and exhibit local minima in regions with high surface elevation where 


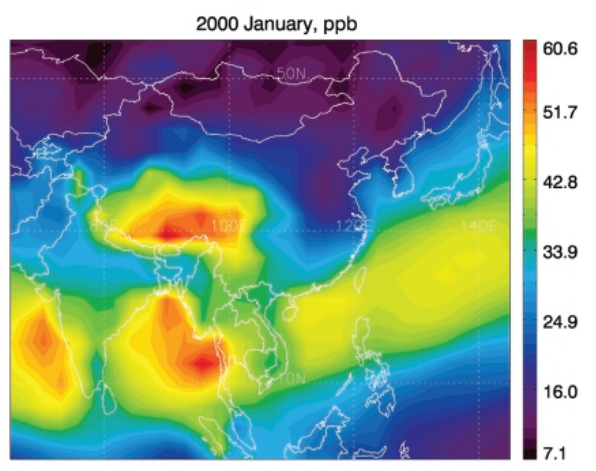

2000 January, DU

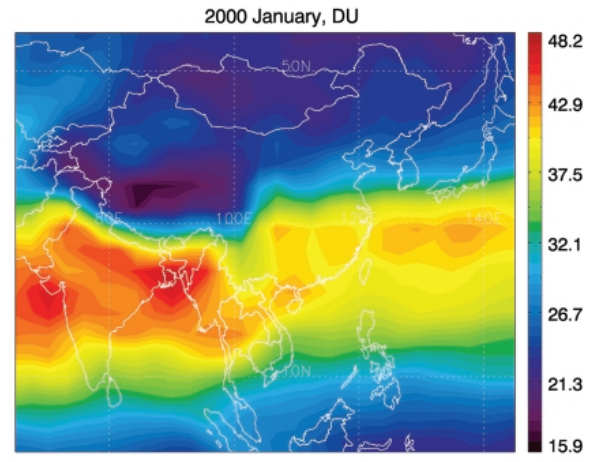

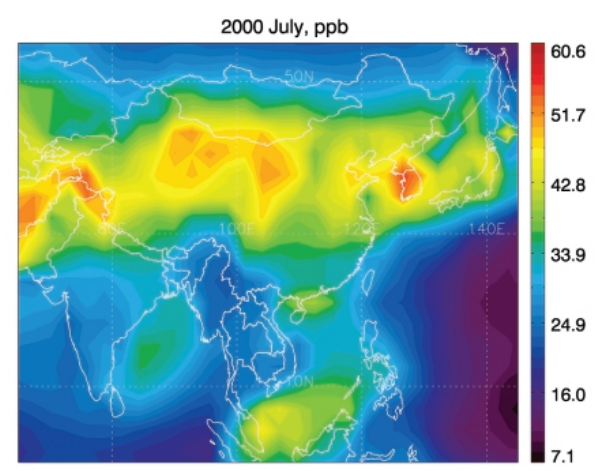

2000 July, DU

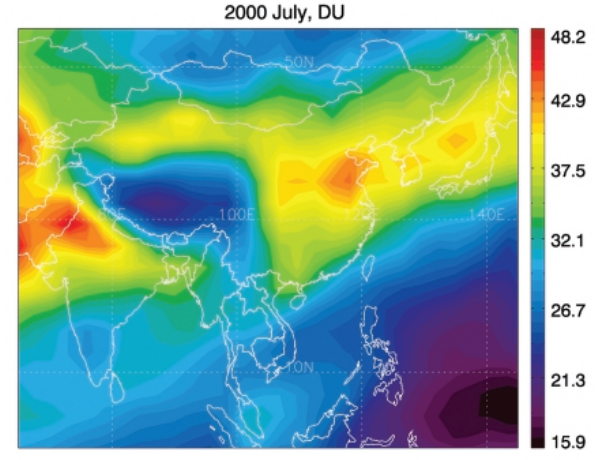

Fig. 4. Monthly-mean surface mixing ratio (top panels, ppb) and tropospheric columns (bottom panels, DU) of ozone in Southeast and East Asia in January and July 2000 as modeled by CTM2.

the tropospheric layer is comparatively thin, and over remote marine areas characterized by low ozone precursor levels and high humidity. For a detailed evaluation of ozone distributions in CTM2 and other models that have participated in the ACCENT experiment the reader is referred to Stevenson et al. (2006).

Figures 5 and 6 show changes in ozone near-surface mixing ratio and tropospheric ozone columns, respectively, for the three different future scenarios. It has to be noted that the changes in ozone presented here are a result not only from increasing $\mathrm{NO}_{\mathrm{x}}$ emissions but also from the increase in other ozone precursors such as carbon monoxide and volatile organic carbons. Furthermore, ozone has a longer lifetime in the troposphere than $\mathrm{NO}_{\mathrm{x}}$ and is thus influenced to a larger degree by transport processes. Finally, being a secondary pollutant produced by photochemical reactions in the atmosphere, ozone distributions are also affected by the availability of sunlight.

In the CLE scenario in January (top left panel in Fig. 5), the largest surface ozone increases are modeled off the coast of India amounting to about $15 \mathrm{ppb}(30 \%)$ in excess of the year 2000 value. This reflects transport of ozone precursors from the main emission sources 
situated along the coast line and subsequent ozone production, particularly from $\mathrm{NO}_{\mathrm{x}}$, in remote areas. During summer, maximum increases are modeled over Northern India. During this time of the year more sunlight is available there to promote photochemical ozone production, at the same time as there is less transport of pollutants from the coast to marine areas as wind advection goes predominantly from the sea towards the coast. The signal from increasing emissions is thus significantly reduced over marine areas. The eastern part of China is characterized by decreases in winter (about $-5 \mathrm{ppb}$ or $-20 \%$ ) and slight increases in summer (on the order of +2 to $+5 \mathrm{ppb}$ or +5 to $+15 \%$ depending on location), being a result of the competing
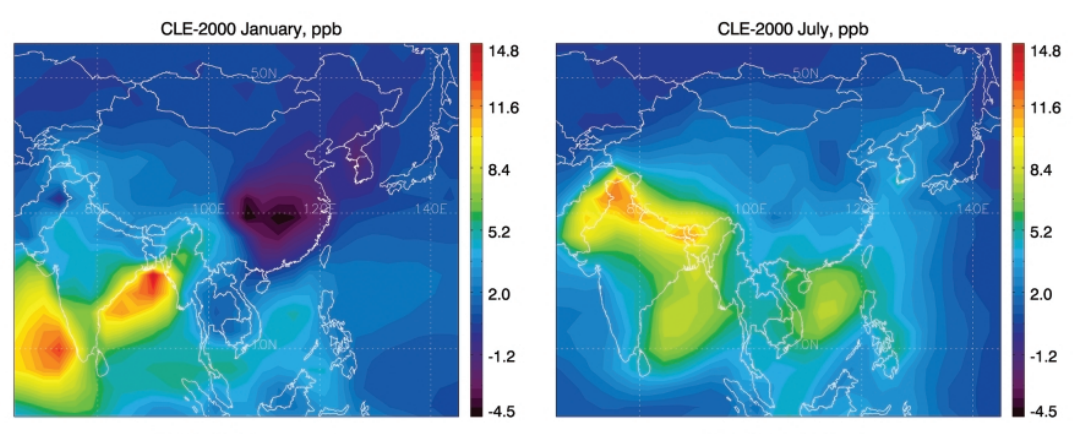

MFR-2000 January, ppb

MFR-2000 July, ppb
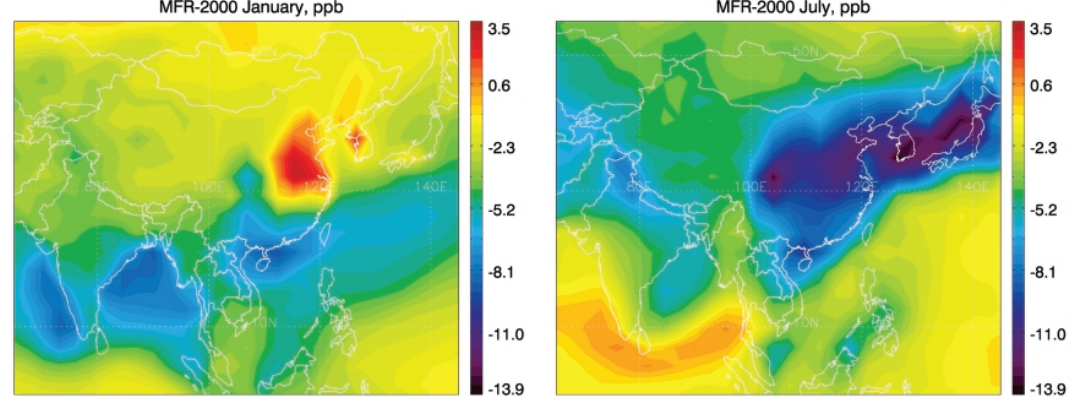

A2-2000 January, ppb

A2-2000 July, ppb
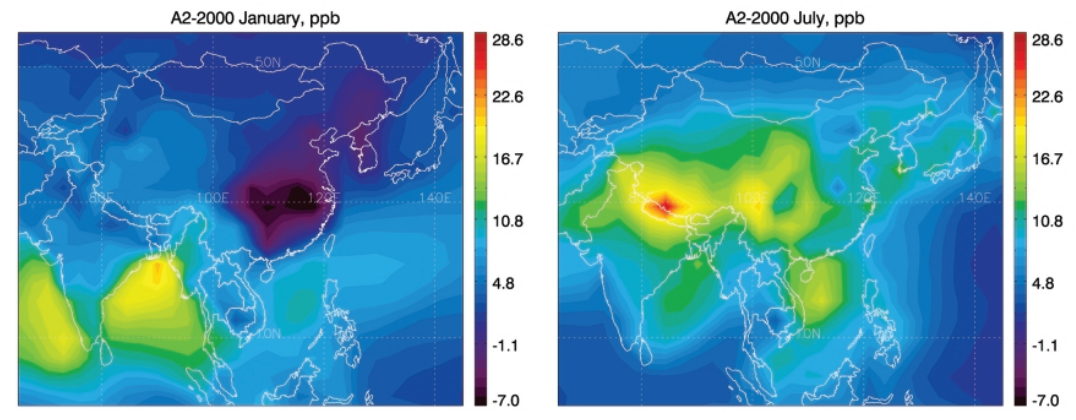

Fig. 5. Changes in monthly-mean surface ozone. Top panels: 'CLE minus 2000', middle panels: 'MFR minus 2000', bottom panels: 'A2 minus 2000'. Unit: ppb. Note the different color scale for the different scenarios. 
effects from ozone production and ozone destruction due to $\mathrm{NO}_{\mathrm{x}}$. During winter, titration effects reducing ozone are facilitated by higher $\mathrm{NO}_{\mathrm{x}}$ concentrations and higher solar zenith angles, while during summer photochemical ozone production dominates.

Seasonal differences are even more pronounced for near-surface ozone in the MFR case (middle panels of Fig. 5), in particular over Eastern China, where an increase is modeled for January ( $3.5 \mathrm{ppb}$ or $25 \%$ in an extended area south of Beijing) and a substantial reduction by typically $25 \%$ is calculated for July. Since there is no seasonal variation in the emission numbers
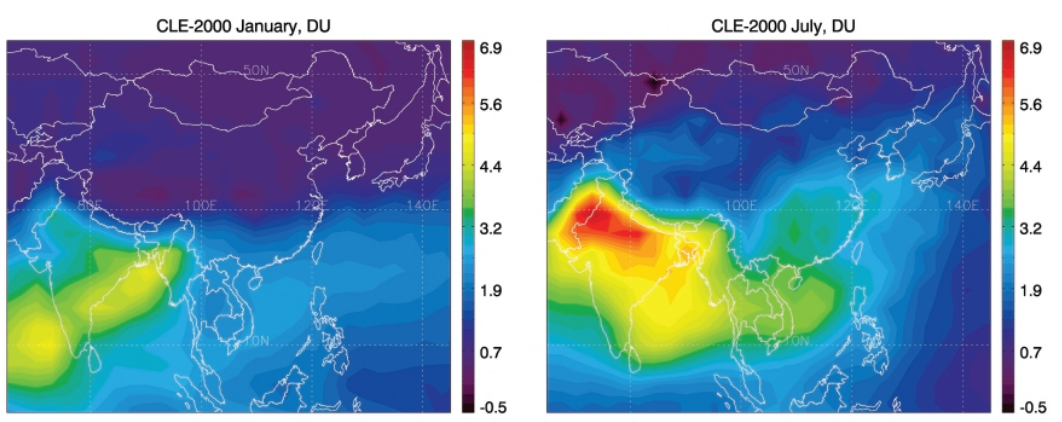

MFR-2000 January, DU
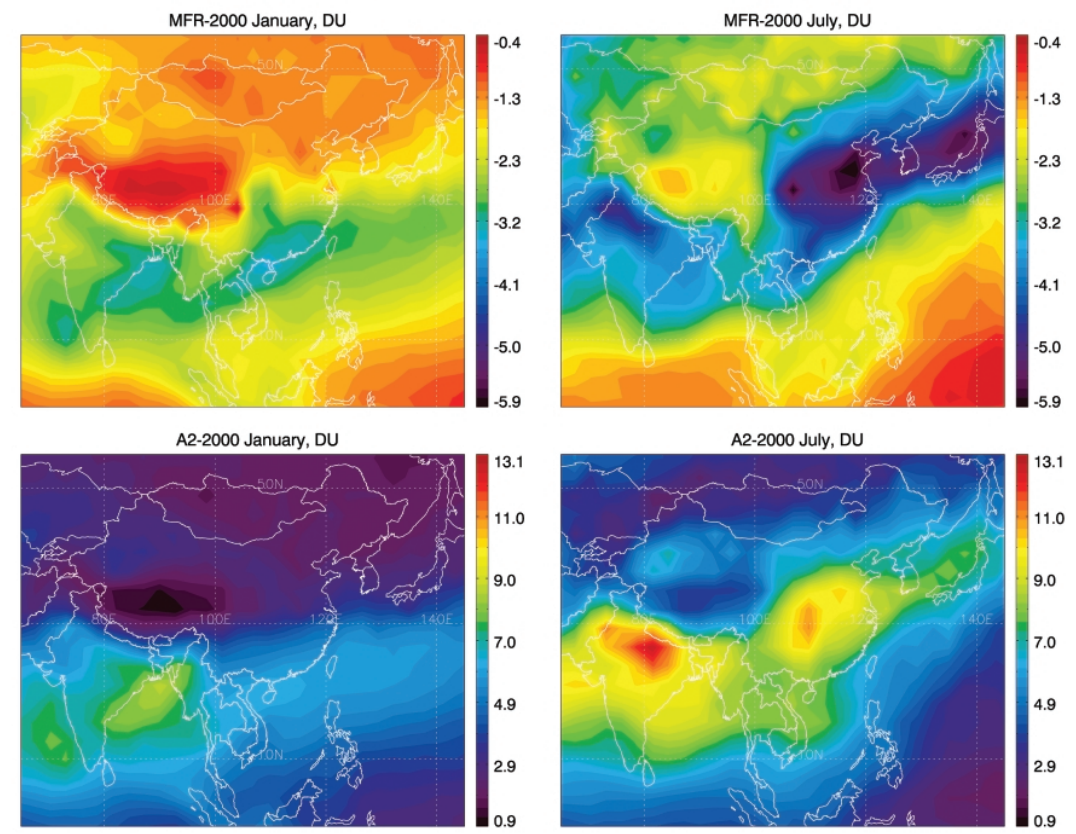

Fig. 6. Changes in the monthly-mean tropospheric ozone column. Top panels: 'CLE minus 2000', middle panels: 'MFR minus 2000', bottom panels: 'A2 minus 2000'. Unit: DU. Note the different color scale for the different scenarios. 
the seasonal cycle must be solely due to chemistry and transport. Reductions in $\mathrm{NO}_{2}$ weaken both the titration effect (i.e., less ozone destruction) and the oxidation of carbon monoxide and hydrocarbons (i.e., less ozone production). During winter the effect of changes in titration dominates since it is independent of sunlight. In other words, there is a net increase in ozone because its destruction is reduced. In summer the effect of decreased photochemical ozone production dominates, i.e., ozone is reduced. Over marine areas south of India the situation is opposite since there, even in the MFR scenario, slight increases in $\mathrm{NO}_{\mathrm{x}}$ are modeled (see Fig. 2).

The pattern of changes in near-surface ozone in the A2 case (bottom panels of Fig. 5) closely resembles the pattern seen for the CLE case, but with much larger perturbations, reflecting the larger increase in ozone precursors. Significant titration leads to reductions by up to $7 \mathrm{ppb}$ (almost 40\%) in Eastern China.

Changes in the tropospheric ozone column (Fig. 6) are determined not only by changes in surface emissions but also by convective and long-range transport of ozone and its precursors. Reductions in the ozone column are hardly seen, neither in the CLE case nor in the A2 case, as titration effects near the surface are overwhelmed by increases in ozone in the free troposphere. The CLE scenario yields significant ozone column increases in India in both summer ( $7 \mathrm{ppb}$ or up to $16 \%$ ) and winter (4 ppb or up to $10 \%$ ), and in areas further to the east only during summer. Increases modeled over China are small in comparison. In the A2 scenario ozone column increases are substantial also over China, connected with the large emission increases in this scenario. Indeed, during summer, large parts of Southeast China are calculated to experience increases by more than $10 \mathrm{DU}$ (about 20 to 30\% depending on location) with respect to the year 2000 case.

In the MFR scenario reductions in column ozone are seen over the entire area. Reductions in January are confined to regions south of 25 degrees north, in particular in coastal regions of eastern India where the ozone column decreases by up to $4 \mathrm{ppb}(7 \%)$ and in southern China with similar changes. During summer, substantial reductions are seen in Eastern China amounting to about 6 DU (about 10 to 15\%) in the region south of Beijing.

\section{CONCLUSIONS}

Near-future (year 2030) changes in $\mathrm{NO}_{2}$ and ozone have been calculated for Southeast and East Asia with the chemical transport model Oslo CTM-2, using emission scenarios provided by IIASA and IPCC-SRES. Increases in $\mathrm{NO}_{2}$ and are modeled in most areas for the IIASA 'current legislation' and SRES-A2 scenarios, while reductions are seen in the IIASA 'maximum feasible reduction' case. Changes in ozone largely reflect changes in $\mathrm{NO}_{\mathrm{x}}$ emissions, with increases over most regions. During high- $\mathrm{NO}_{\mathrm{x}}$ episodes, especially in winter, near-surface ozone levels may decrease locally due to titration effects.

Different aspects of these changes have been investigated in recent publications from the ACCENT experiment. Effects of near-surface ozone increases on human health and vegetation, including crop growth, are investigated in Ellingsen et al. (2006), showing that air quality standards and health indices are exceeded more often in the near future. Possible effects of changes in ozone on radiative forcing are investigated on a global scale by Stevenson et al. (2006) and Dentener et al. (2006b). 
It is important to note that, even if current legislation is fully implemented as in the CLE case, both surface levels and column abundances of $\mathrm{NO}_{2}$ and ozone increase in many populated areas, in particular over India. At the same time it is encouraging that the currently available technology for emission reductions (MFR) would, in terms of air quality, fully compensate for the increase in energy consumption and even allow for reductions in $\mathrm{NO}_{2}$ and ozone levels.

The uncertainties in emission scenarios for the Southeast and East Asian regions remain large, as is reflected by the range of emission numbers in the different scenarios available to date. Also, it is unclear if the locations of each emission source will remain the same during the period 2000 to 2030. Given the possibility of future population increase in India, Southeast Asia and China, new areas are likely to be populated and developed, thus changing the spatial distribution of emissions from what is was in the year 2000. Nonetheless it is clear from our model calculations that the implementation of available clean technology and of carefully devised mitigation strategies is necessary to ensure an acceptable air quality in Southeast and East Asia also for the next generations.

Acknowledgement This study has been supported by the European Commission through ACCENT, a European Network of Excellence within Framework Programme 6.

\section{REFERENCES}

Berglen, T. F., T. K. Berntsen, I. S. A. Isaksen, and J. K. Sundet, 2004: A global model of the coupled sulfur/oxidant chemistry in the troposphere: The sulfur cycle. J. Geophys. Res., 109, doi:10.1029/2003JD003948.

Berntsen, T., and I. S. A. Isaksen, 1997: A global 3-D chemical transport model for the troposphere, 1, Model description and CO and Ozone results. J. Geophys. Res., 102, 21239-21280.

Berntsen, T. K., and I. S. A. Isaksen, 1999: Effects of lightning and convection on changes in upper tropospheric ozone due to aircraft. Tellus, 51B, 766-788.

Baughcum, S. L., S. C. Henderson, T. G. Tritz, and D. C. Pickett, 1996: Scheduled Civil Aircraft Emission Inventories for 1992: Database Development and Analysis. NASACR-4700, NASA, Langley Research Center, Hampton, VA, USA.

Boudri, J. C., L. Hordijk, C. Kroeze, M. Amann, J. Cofala, I. Bertok, L. Junfeng, D. Lin, Z. Shuang, H. Runquing, T. S. Panwar, S. Gupta, D. Singh, A. Kumar, M. C. Vipradas, P. Dadhich, N. S. Prasad, and L. Srivastava, 2002: The potential contribution of renewable energy in air pollution abatement in China and India. Energy Policy, 30, 409-424.

Brunner, D., J. Staehelin, H. L. Rogers, M. O. Kohler, J. A. Pyle, D. A. Hauglustaine, L. Jourdain, T. K. Berntsen, M. Gauss, I. S. A. Isaksen, E. Meijer, P. van Velthoven, G. Pitari, E. Mancini, V. Grewe, and R. Sausen, 2005: An evaluation of the performance of chemistry transport models - Part 2: Detailed comparison with two selected campaigns. Atmos. Chem. Phys., 5, 107-129.

Cofala, J., M. Amann, and R. Mechler, 2006: Scenarios of world anthropogenic emissions of 
air pollutants and methane up to 2030, IR-06-023, International Institute for Applied Systems Analysis, Laxenburg, Austria.

Dentener, F., D. Stevenson, J. Cofala, R. Mechler, M. Amann, P. Bergamaschi, F. Raes, and R. Derwent, 2005: The impact of air pollutant and methane emission controls on tropospheric ozone and radiative forcing: CTM calculations for the period $1990-2030$. Atmos. Chem. Phys., 5, 1731-1755.

Dentener, F., J. Drevet, J. F. Lamarque, I. Bey, B. Eickhout, A. M. Fiore, D. Hauglustaine, L. W. Horowitz, M. Krol, U. C. Kulshrestha, M. Lawrence, C. Galy-Lacaux, S. Rast, D. Shindell, D. Stevenson, T. Van Noije, C. Atherton, N. Bell, D. Bergman, T. Butler, J. Cofala, B. Collins, R. Doherty, K. Ellingsen, J. Galloway, M. Gauss, V. Montanaro, J. F. Muller, G. Pitari, J. Rodriguez, M. Sanderson, F. Solmon, S. Strahan, M. Schultz, K. Sudo, S. Szopa, and O. Wild, 2006a: Nitrogen and sulfur deposition on regional and global scales: A multi-model evaluation. Global Biogeochemical Cycles, 20, GB4003, doi:10.1029/2005GB002672.

Dentener, F., D. Stevenson, K. Ellingsen, T. van Noije, M. Schultz, M. Amann, C. Atherton, N. Bell, D. Bergmann, I. Bey, L. Bouwman, T. Butler, J. Cofala, B. Collins, J. Drevet, R. Doherty, B. Eickhout, H. Eskes, A. Fiore, M. Gauss, D. Hauglustaine, L. Horowitz, I. S. A. Isaksen, B. Josse, M. Lawrence, M. Krol, J. F. Lamarque, V. Montanaro, J. F. Muller, V. H. Peuch, G. Pitari, J. Pyle, S. Rast, J. Rodriguez, M. Sanderson, N. H. Savage, D. Shindell, S. Strahan, S. Szopa, K. Sudo, R. van Dingenen, O. Wild, and G. Zeng, 2006b: The global atmospheric environment for the next generation. Environ. Sci. Technol., 40, 3586-3594.

Ellingsen, R. van Dingenen, F. Dentener, L. Emberson, A. M. Fiore, M. G. Schultz, D. S. Stevenson, M. Gauss, M. Amann, C. S. Atherton, N. Bell, D. J. Bergmann, I. Bey, T. Butler, J. Cofala, W. J. Collins, R. G. Derwent, R. M. Doherty, J. Drevet, H. Eskes, D. Hauglustaine, I. S. A. Isaksen, L. W. Horowitz, M. Krol, J. F. Lamarque, M. Lawrence, V. Montanaro, J. F. Muller, T. van Noije, G. Pitari, M. J. Prather, J. Pyle, S. Rast, J. Rodriguez, M. Sanderson, N. Savage, D. Shindell, S. Strahan, K. Sudo, S. Szopa, O. Wild, G. Zeng, 2006: Ozone air quality in 2030: A multi model assessment of risks for health and vegetation. Atmos. Chem. Phys. Discuss., manuscript in preparation.

Gauss, M., G. Myhre, I. S. A. Isaksen, V. Grewe, G. Pitari, O. Wild, W. J. Collins, F. J. Dentener, K. Ellingsen, L. K. Gohar, D. A. Hauglustaine, D. Iachetti, J. F. Lamarque, E. Mancini, L. J. Mickley, M. J. Prather, J. A. Pyle, M. G. Sanderson, K. P. Shine, D. S. Stevenson, K. Sudo, S. Szopa, and G., Zeng, 2006a: Radiative forcing since preindustrial times due to ozone change in the troposphere and the lower stratosphere. Atmos. Chem. Phys., 6, 575-599.

Gauss, M., I. S. A. Isaksen, D. S. Lee, and O. A. Sovde, 2006b: Impact of aircraft $\mathrm{NO}_{\mathrm{x}}$ emissions on the atmosphere - Tradeoffs to reduce the impact. Atmos. Chem. Phys., 6, 15291548.

Hesstvedt, E., O. Hov, I. S. A. Isaksen, 1978: Quasi steady-state approximation in air pollution modelling: Comparison of two numerical schemes for oxidant prediction. Int. J. Chem. Kinetics, X, 971-994.

Holtslag, A. A. M., E. I . F. DrBruijn, and H. L. Pan, 1990: A High resolution air mass transformation model for short-range weather forecasting. Mon. Weather Rev., 118, 1561-1575. 
IIASA: RAINS-Asia, 2001 International Institute for Applied Systems Analysis, Laxenburg, Austria (website at http://www.iiasa.ac.at/ rains/home.html).

IMF (International Monetary Fund), 2006: "Asia and Pacific Regional Economic Outlook May 2006" prepared by a team consisting of: Aisen, A., J. Aziz, R. Brooks, D. Cowen, S. Creane, L. Cui, G. Dell'Ariccia, J. Felman, C. Kramer, J. Miniane, C. Morris, A. Richter Hume, R. Semblat, N. Thacker, and P. Tumbarello, available at the website of the International Monetary Fund at http://www.imf.org.

Isaksen, I. S. A., C. S. Zerefos, K. Kourtidis, C. Meleti, S. B. Dalsoren, J. K. Sundet, A. Grini, P. Zanis, D. Balis, 2005: Tropospheric ozone changes at unpolluted and semipolluted regions induced by stratospheric ozone changes. J. Geophys. Res., 110, doi: 10.1029/ 2004JD004618.

Liu, L., J. K. Sundet, Y. Liu, T. K. Berntsen, and I. S. A. Isaksen, 2007: A study of tropospheric ozone over China with a 3-D global CTM model. Terr. Atmos. Ocean. Sci., 18, 515-545, doi: 10.3319/TAO.2007.18.3.515(EA).

Nakicenovic, N., J. Alcamo, G. Davis, B. de Vries, J. Fenhann, S. Gaffin, K. Gregory, A. Grubler, T. Y. Jung, T. Kram, E. L. La Rovere, L. Michaelis, S. Mori, T. Morita, W. Pepper, H. Pitcher, L. Price, K. Raihi, A. Roehrl, H. H. Rogner, A. Sankovski, M. Schlesinger, P. Shukla, S. Smith, R. Swart, S. van Rooijen, N. Victor, and Z. Dadi, 2000: Emissions Scenarios, A special Report of Working Group III of the Intergovernmental Panel on Climate Change. Cambridge University Press, Cambridge, United Kingdom and New York, NY, USA, 599 pp.

Olivier, J. G. J., and J. J. M. Berdowski, 2001: Global emissions sources and sinks. In: Berdowski, J. J. M., R. Guicherit, and B. J. Heij (Eds.), The Climate System, Swets \& Zeitlinger, Lisse, The Netherlands, 33-78.

Prather, M. J., 1986: Numerical advection by conservation of second-order moments. $J$. Geophys. Res., 91, 6671-6681.

Prather, M., D. Ehhalt, F. Dentener, R. Derwent, E. Dlugokencky, E. Holland, I. Isaksen, J. Katima, V. Kirchhoff, P. Matson, P. Midgley, and M. Wang, 2001: Atmospheric Chemistry and Greenhouse Gases. In: Houghton, J. T., Y. Ding, D. J. Griggs, M. Noguer, P. J. van der Linden, X. Dai, K. Maskell, and C. A. Johnson (Eds.), Climate Change 2001: The Scientific Basis. Contribution of Working Group I to the Third Assessment Report of the Intergovernmental Panel on Climate Change (IPCC), Cambridge University Press, Cambridge, United Kingdom and New York, NY, USA, 881 pp.

Prather, M., M. Gauss, T. Berntsen, I. Isaksen, J. Sundet, I. Bey, G. Brasseur, F. Dentener, R. Derwent, D. Stevenson, L. Grenfell, D. Hauglustaine, L. Horowitz, D. Jacob, L. Mickley, M. Lawrence, R. von Kuhlmann, J. F. Muller, G. Pitari, H. Rogers, Helen, M. Johnson, J. Pyle, K. Law, M. van Weele, and O. Wild, 2003: Fresh air in the 21st century? Geophys. Res. Lett., 30, doi:10.1029/2002GL016285.

Price, C., J. Penner, and M. Prather, 1997a: $\mathrm{NO}_{\mathrm{x}}$ from lightning 1. Global distribution based on lightning physics. J. Geophys. Res., 102, 5929-5942.

Price, C., J. Penner, and M. Prather, 1997b: $\mathrm{NO}_{\mathrm{x}}$ from lightning 2. Constraints from the global atmospheric circuit. J. Geophys. Res., 102, 5943-5952.

Shindell, D. T., G. Faluvegi, D. S. Stevenson, M. C. Krol, L. K. Emmons, J. F. Lamarque, G. Petron, F. J. Dentener, K. Ellingsen, M. G. Schultz, O. Wild, M. Amann, C. S. Atherton, 
D. J. Bergmann, I. Bey, T. Butler, J. Cofala, W. J. Collins, R. G. Derwent, R. M. Doherty, J. Drevet, H. J. Eskes, A. M. Fiore, M. Gauss, D. A. Hauglustaine, L. W. Horowitz, I. S. A. Isaksen, M. G. Lawrence, V. Montanaro, J. F. Muller, G. Pitari, M. J. Prather, J. A. Pyle, S. Rast, J. M. Rodriguez, M.G. Sanderson, N. H. Savage, S. E. Strahan, K. Sudo, S. Szopa, N. Unger, T. P. C. van Noije, and G. Zeng, 2006: Multi-model simulations of carbon monoxide: Comparison with observations and projected near-future changes. $J$. Geophys. Res., 111, D19306, doi: 10.1029/2006JD007100.

Stevenson, D. S., F. J. Dentener, M. G. Schultz, K. Ellingsen, T. P. C. van Noije, O. Wild, G. Zeng, M. Amann, C. S. Atherton, N. Bell, D. J. Bergmann, I. Bey, T. Butler, J. Cofala, W. J. Collins, R. G. Derwent, R. M. Doherty, J. Drevet, H. J. Eskes, A. M. Fiore, M. Gauss, D. A. Hauglustaine, L. W. Horowitz, I. S. A. Isaksen, M. C. Krol, J. F. Lamarque, M. G. Lawrence, V. Montanaro, J. F. Muller, G. Pitari, M. J. Prather, J. A. Pyle, S. Rast, J. M. Rodriguez, M. G. Sanderson, N. H. Savage, D. T. Shindell, S. E. Strahan, K. Sudo, and S. Szopa, 2006: Multi-model ensemble simulations of present-day and nearfuture tropospheric ozone. J. Geophys. Res., 111, D08301, doi:10.1029/2005JD006338.

Tiedtke, M., 1989: A comprehensive mass flux scheme for cumulus parameterisation on large scale models. Mon. Weather, Rev., 117, 1779-1800.

van der Werf, G. R., J. T. Randerson, G. J. Collatz, and L. Giglio, 2003: Carbon emissions from fires in tropical and subtropical ecosystems. Global Change Biol., 9, 547-562.

van Noije, T. P. C., H. J. Eskes, F. J. Dentener, D. S. Stevenson, K. Ellingsen, M. G. Schultz, O. Wild, M. Amann, C. S. Atherton, D. J. Bergmann, I. Bey, K. F. Boersma, T. Butler, J. Cofala, J. Drevet, A. M. Fiore, M. Gauss, D. A. Hauglustaine, L. W. Horowitz, I. S. A. Isaksen, M. C. Krol, J. F. Lamarque, M. G. Lawrence, R. V. Martin, V. Montanaro, J. F. Muller, G. Pitari, M. J. Prather, J. A. Pyle, A. Richter, J. M. Rodriguez, N. H. Savage, S. E. Strahan, K. Sudo, S. Szopa, and M. van Roozendael, 2006: Multi-model ensemble simulations of tropospheric $\mathrm{NO}_{2}$ compared with GOME retrievals for the year 2000. Atmos. Chem. Phys., 6, 2943-2979.

Wesely, M. L., 1989: Parameterization of surface resistances to gaseous dry deposition in regional-scale numerical models. Atmos. Environ., 23, 1293-1304.

Wild, O., X. Zhu, and M. J. Prather, 2000: Fast-J: Accurate simulation of in- and below cloud photolysis in tropospheric chemical models. J. Atmos. Chem., 37, 245-282.

Gauss, M., K. Ellingsen, I. S. A. Isaksen, F. J. Dentener, D. S. Stevenson, M. Amann, and J. Cofala, 2007: Changes in nitrogen dioxide and ozone over Southeast and East Asia between year 2000 and 2030 with fixed meteorology. Terr. Atmos. Ocean. Sci., 18, 475-492, doi: 10.3319/TAO.2007.18.3.475(EA). 